\title{
IMPROVE TECHNOPRENEURSHIP LEARNING OUTCOMES WITH COOPERATIVE LEARNING METHOD "FLASH CARD GAME" AND "QUIZ-QUIZ TRADE" AMONG VOCATIONAL HIGH SCHOOL STUDENT
}

\author{
Hari Kurniawan ${ }^{1}$ \\ ${ }^{1}$ Entrepreneurship Education, SMK Tempursari \\ Email: harikurniawan1985@gmail.com
}

\begin{abstract}
:
Selection of teaching methods largely determine the quality of teaching in the learning process, to achieve the learning objectives required the use of an optimal learning method. This means that to achieve quality teaching, each teaching should be organized on a student with appropriate learning methods.
\end{abstract}

One model of learning according to researchers who can improve the skills of process and student learning outcomes is a model of cooperative learning approach Flash card games and quiz - quiz trade, The advantages of cooperative learning model of the Flash card games and quiz quiz trade is make material more attractiveto students.

The learning process Flash card games and quiz - quiz trade push to listen, clarification, connect description between several variables, making predictions, dealing, communicate, and is responsible to give each member of the famil important group are discussed in academic activities.

This is according to research Sakdiyah (2002) which states that students who are taught by the model of cooperative learning methods Flash card games and quiz - quiz trade have higher achievement than students taught using conventional teaching methods.

Keywords: FLASH CARD GAMES, QUIZ-QUIZ TRADE, STUDY MOTIVATION, LEARNING OUTCOMES, TECHNOPRENEURSHIP

\section{Background}

Education that can support the future development is education that develops students' potential so concerned is able to face and solve the problems of life faces. Education must touch the inner potential and the potential of student competence. The educational concept was even more important when a person has to enter the life in society and the world of work as concerned should be able to apply what is learned in school to overcome problems faced in everyday life.

Vocational School (SMK) to implement such a curriculum set by the government. Where it has been structured education and training programs are divided into three namely: Normative, Adaptive and Productive. For the category of Normative it includes religious subjects, Civics, Indonesian, and History. Adaptive group is Mathematics, Physics, English, Chemistry and Computer. Meanwhile, the productive groups, especially the Department of Mechanical audio and video are working workshop and drawing techniques, basic electricity and Technopreneurship, Technopreneurship circuit implementation, planning the installation of audio-video systems and so forth. Thirdly the government-set curriculum complements and support the student's skills especially in the group category of adaptive and productive.

SMK Tempursari Lumajang East Java is one part of the formal education that has 6 (six) courses. One of them is the Technique Audio Video. Audio Video Engineering Department has several wholly used as the title of competence training eye. One of the subjects that are in electricity and Technopreneurship with one area 
of the material introduced is the introduction Symbols Electrical Components and Technopreneurship and its application to the circuit Technopreneurship. This training eye given in the first semester of class $X$ number of basic components that must be mastered by the student without any basic practices require solutions that can be implemented to encourage students to discuss, help each other to complete the task, master and eventually apply the skills given to improve learning outcomes is by changing the way learning and using model with a model that aims to stimulate cooperative learning activity of students in learning. One model of learning is learning model application Flash Card Game and Quiz Quiz Trade on the introduction of the material symbols of electrical components and Technopreneurship.

By applying the principles of learning model Flashcard Game and Quiz-Quiz Trade can increase the effectiveness of student learning and improve student mastery of the competencies ability to understand symbols in class $\mathrm{X}$ Technopreneurship components Mechanical Audio Video.

\section{Learning means}

Rohani say thats learning outcomes according to the progress of learners in mastering the subject matter learned in accordance with its intended purpose. Meanwhile, according to Winarno Surahmad (1997: 88) as follows: learning outcomes are the results where teachers see the final shape of the experience of educational interaction that is considered is placing behavior. Meanwhile, in the opinion of Arikunto Suharsimi, learning outcomes is the end after undergoing a process of learning, which behavior it appears in the form of acts that can be observed and measured. Learning in this study was defined all the effort given by the teacher in order to receive and be able to master what has been received in this regard is the Basic lessons Etechnopreneurship Mechanical Audio Video.

\section{Learning Outcomes}

To get good results in learning, we are fully convinced that the teacher is very critical to the success of student learning outcomes. Dr. Georgi Lozanov, a Bulgarian researcher who is also the inventor of science suggestology, a method known collectively as accelerated learning sccara show that pengarug Master is so clearly against kcsuksesan pupil (Lovanov, 1978).

Dr. Michal Gazzaniga agreed, "The impetus was a natural Biological simple. Ability or new skills will thrive if given the appropriate model environment "(Gazzaniga, 1992) The teacher is an important factor in the learning environment and student environment. So, the role of the teacher is more than just a giver of knowledge, teachers are peer learning, models, mentors, facilitators are not any longer as a modifier of student success.

Research also shows that the social environment or atmosphere of the class is a determinant of primary psychological affecting belaja academic (Walberg and Greenberg, 1997) We have faith and believe strongly that in starting the adventure of learning, level of commitment and dedication is needed to study the present and in order to form a learning community that supports optimal learning contexts need to arrange the ideal learning stage are:

1. Class situation

The classroom atmosphere includes the selected language, how to establish a sense of sympathy with the students and attitudes to school and learning. The atmosphere is full of excitement in learning

2. Platform

The cornerstone is the framework, objectives, beliefs, agreements, policies, procedures and rules along with providing guidance in working in a learning community.

3. Environment

is how to organize the classroom, lighting, color, arrangement of tables and chairs, plants, music and all the things that support the learning process.

4 draft

The design is purposeful creation of critical elements which can cultivate students' interest, to explore the meaning and understand the process of information exchange.

If all four of these aspects laid out carefully, a miracle will happen. Context really creates a sense of belonging, which in turn will increase the sense of belonging and appreciation, the class will be learning community, precisely the destination of the students happy, not because of compulsion.

Akfivitas learning has the sense of a mental / psychic that takes place in an active interaction with the environment that result in changes in knowledge, comprehension, understanding, skills and value attitudes. In this study, the results belajajar terms of cognitive development, including enhancing knowledge and understanding of Iebih emphasis on cognitive aspects 6 directions, namely: knowledge, comprehension, application, analysis, synthesis and evaluation.

Learning outcomes are the results achieved by students after attending a series of specific instructional activities. Learning outcomes achieved by students is closely related to the formulation of instructional planned by the previous teacher. The results and evidence of learning is the change in 
behavior of people are learning that occurs due to the process of maturity and learning outcomes are relatively sedentary, for example dati not knowing to knowing and of not understanding be understood. According Mudjiono (2000), that the results and evidence of learning is a change in the behavior of those who learn.

According to Howard Kingsley (Sudjana, 1989), there are three types of learning outcomes: (a) the skills and habits, (b) knowledge and understanding, (c) attitudes and ideals, which can each group, can be filled with a material implemented in the school curriculum. Benjamin Bloom found educational goals that we wish to accomplish consists of three areas, namely the cognitive field, the field of affective and psychomotor fields.

Any activity that takes place in the end we would like to know the results, as well as learning. To find out the results of learning activities, to be carried out measurement and assessment. Measurement is an attempt to find something as it is, while the assessment is an effort that aims to determine the success of learning in the mastery of competencies (Haling, 2002). Thus, the measurement of learning outcomes is an attempt to find out the status of competence by using a measuring instrument in accordance with what is being measured, while the assessment is an attempt to compare the measurement results with the specified benchmark.

\section{Learning Outcomes TechnopreneurshipMaterial}

As has been explained previously that the learning outcomes are the results achieved by students after attending a series of specific instructional activities. So the basic learning outcomes - basictechnopreneurshipis the learning outcomes achieved by students is closely related to the formulation of instructional planned by previous teachers in this regard is the adjustment of the achievement of the indicators of success criteria in learning outcomes or completeness criteria Minimal (KKM) that has been set by a teacher before teaching the syllabus and Plans Learning implementation (RPP). In this case of course, a teacher should first determine Competence Standard and Basic Competence what will be taught in pembelaran activities which have all been stated in Learning Implementation Plan (RPP) and syllabus in this case is the subject Basic - Basic Technopreneurship.

Basic - Basic technopreneurshipis one of the vocational subject's audio-video techniques in SMK. Even most subjects there are already a vocational training eye on the video audio engineering. Achieved learning outcomes can be seen through the results of learning theory or practice during the learning activities and of course referring to the Learning Implementation Plan (RPP) and syllabus used at the time Teaching and learning activities (KBM).

\section{Learning Model}

The model is designed to represent the true reality, although the model is not the reality of the real world. On the basis of such understanding, the teaching model can be understood as a conceptual framework to describe and depict systematic procedure in organizing the learning experience and learning to achieve certain learning, and serves as a guide for planning instruction for teachers in implementing the learning activity (Sagala 2005 : 176).

The learning model is specially planned learning patterns to achieve specific learning objectives (Agustian, 2004: 8). Real learning model is prepared to learn, where teachers help students to acquire information, ideas, skills, values, ways of thinking and expressing themselves (Joyce et al, 2009: 7).

\section{Cooperative Learning Model}

Cooperative learning is one of the forms of learning based on constructivist ideology. Cooperative learning is learning strategy with a number of students as a member of a small group of different ability levels. In completing the task group, each student member of the group must work together and help each other to understand the subject matter. In cooperative learning, learning is not yet finished when one of the friends in the group have not mastered the learning material

Cooperative learning is an instructional model that promotes cooperation among students to achieve the learning objectives. Cooperative learning has these characteristics:

1. To memuntaskan learning materials, students learn in a group is working together

2. The group was formed from students who have high capability, medium and low

3. If in a class there are students who heterogeneous race, ethnicity, culture and gender, it is necessary that each of the groups, there is heterogeneity.

4. Preferably appreciation on the work group rather than individually.

Cooperative Learning Objectives

1. The results of an academic study, which is to improve student performance preformance academic tasks. Learning of this model is considered superior in helping students understand difficult concepts. 
2. Acceptance of diversity, namely that students receive friends who have various backgrounds.

3. Development of social skills, which is to develop the social skills of students include: sharing tasks, actively ask, respect the opinions of others, a fishing friend to ask, want to express ideas, and work in groups.

4. Phases of Cooperative Learning Model:

\begin{tabular}{|c|c|c|}
\hline $\begin{array}{c}\text { phas } \\
\text { e }\end{array}$ & Indicator & Teacher activity \\
\hline 1 & $\begin{array}{l}\text { Outlines the objectives } \\
\text { and motivate students }\end{array}$ & $\begin{array}{l}\text { The teacher presents all the } \\
\text { learning objectives to be achieved } \\
\text { in these subjects and motivate } \\
\text { students }\end{array}$ \\
\hline 2 & Presenting information & $\begin{array}{l}\text { Teachers present information to } \\
\text { students with street demonstrations } \\
\text { or through the reading material }\end{array}$ \\
\hline 3 & $\begin{array}{l}\text { Organizing students } \\
\text { into study groups }\end{array}$ & $\begin{array}{l}\text { Teachers explain to students how } \\
\text { to form study groups and help each } \\
\text { group to perform efficient } \\
\text { transition }\end{array}$ \\
\hline 4 & $\begin{array}{l}\text { Guiding the group work } \\
\text { and study }\end{array}$ & $\begin{array}{l}\text { Teachers guide study groups at the } \\
\text { time of assignment }\end{array}$ \\
\hline 5 & Evaluation & $\begin{array}{l}\text { Teachers evaluate learning } \\
\text { outcomes of the material that has } \\
\text { been learned or each group } \\
\text { presented their work }\end{array}$ \\
\hline 6 & reward & $\begin{array}{l}\text { Teachers looking for ways to } \\
\text { reward effort or student learning } \\
\text { outcomes, both individuals and } \\
\text { groups. }\end{array}$ \\
\hline
\end{tabular}

Learning Model Flashcard Game and Quiz-Quiz Trade

Flashcard Games and Quiz-Quiz Tradeis one type of cooperative learning that puts students in groups - a study group. Broadly speaking, the learning model can be understood in the following table.

\section{flashcard GAME}

Partners start through three rounds because they each give a quiz with flascards, master content for the winning cards. Setup: each student has their own set of flashcardsnya.

\begin{tabular}{|c|c|}
\hline 1 & $\begin{array}{l}\text { In pairs, tutee (the parties will be given } \\
\text { a tutorial) provides its kartuflash to Tutor. }\end{array}$ \\
\hline 2 & $\begin{array}{l}\text { Round 1: The existence of many signals } \\
\text { answers. Tutor menunjukkuan questions on the } \\
\text { first card, read the question, and the shows and } \\
\text { reading the written answers in the cards. Tutor } \\
\text { then switch the card and read the questions in } \\
\text { advance to ask the tutee card answers from } \\
\text { memory. }\end{array}$ \\
\hline 3 & $\begin{array}{l}\text { Tutee answered. If true, tutee win back } \\
\text { the card and receive a surprise gift and } \\
\text { menyenagkan of Tutor. If wrong, the tutor shows } \\
\text { the tutee the answer on the card and teach him. } \\
\text { This card is then returned to the original pile and } \\
\text { will be used again. }\end{array}$ \\
\hline 4 & $\begin{array}{l}\text { When tutee won all the cards, partners } \\
\text { switch roles. When the new tutee won all the } \\
\text { cards, developed partners to round (round) to } 2 .\end{array}$ \\
\hline 5 & $\begin{array}{l}\text { Round 2: bit signal response. The } \\
\text { process was repeated, except tutor showed only } \\
\text { question on the face of each card, and ask tutee } \\
\text { the answer from memory. }\end{array}$ \\
\hline 6 & $\begin{array}{l}\text { Round 3: without signal response. The } \\
\text { process was repeated, except tutors provide tutee } \\
\text { quiz to each question without showing tutee } \\
\text { flashcard. }\end{array}$ \\
\hline 7 & $\begin{array}{l}\text { Note: For students who are young, limit } \\
\text { ound no more than } 5 \text { cards. If a student has } \\
\text { li the cards, he can add a bonus card. }\end{array}$ \\
\hline
\end{tabular}

Table Quiz Quiz Trade

Quiz-Quiz-TRADE

Students gave questions to partners, answered by the partners, and then exchange cards to repeat the process with a new partner.

\begin{tabular}{|l|l|}
\hline 1 & $\begin{array}{l}\text { Teachers tell students to stand up, put his hands on, } \\
\text { and pairs. }\end{array}$ \\
\hline 2 & Partner A quizzed B \\
\hline
\end{tabular}




\begin{tabular}{|l|l|}
\hline 3 & Partner B replied. \\
\hline 4 & $\begin{array}{l}\text { Partner A commend (if the answer is correct) or } \\
\text { teach (if partner B can not answer or the answer is } \\
\text { wrong). }\end{array}$ \\
\hline 5 & Partners switch roles. \\
\hline 6 & Partner card exchange and mutual thanked \\
\hline 7 & Repeat steps 1-6 until the specified time runs out. \\
\hline
\end{tabular}

According Learning Kagan flashcard Gamesuitable for use in the form of facts to remember something. This is usually played with the goal of building a team (team building) using the cards that are dealt cards. While Quiz Quiz Trade allows for each team share the card to complete what yes understand the material drawn / written on the card without any change of the next question.

\section{The Nature of Learning Effectiveness}

Learning success can not simply be the learning outcomes achieved by students, but also in terms of the learning process. The learning process occurs when there is an interaction between teachers and students and between students and students, because they have a reciprocal relationship. The effectiveness of teaching methods is a measure related to the level of success of a learning process

Effectiveness is trying to achieve goals that have been set in accordance with the necessary means, in accordance also with the plan, both in the use of the data, the means, nor the time or berusahan through specific activities both physical and nonphysical to obtain maximum results both quantitatively and qualitative.

According to Big Indonesian Dictionary (KBBI) definition of effectiveness is "Something which has the effect or consequences caused, potent, bring results and the success of a business or an action, in this case the effectiveness can be seen from the implementation or otherwise of specific instructional objectives that have been implemented.

The learning method is said to be effective if the specific instructional objectives proclaimed much more accomplished. According Purwadarminta (1994: 32) states that: "In teaching effectiveness with regard to the achievement of objectives, thus the purpose of the analysis is the first activity in the planning of teaching".

Furthermore, Harry's Word (1987: 24) states that: "The effectiveness of the learning program is characterized by the following characteristics: (1) Successful conduct of students achieving instructional objectives that have been set. (2) Provide an attractive learning experience, involving students actively to support the achievement of instructional objectives. (3) Have the means to support the teaching and learning process.

Based on the characteristics of effective learning programs as described above, the effectiveness of learning programs not only in terms of the level of learning achievement alone, but must also be reviewed in terms of processes and supporting infrastructure. Aspects include a review of the results of student learning outcomes after following a learning program that includes the ability of cognitive, affective and psychomotor. Aspects of the process includes observations of student skills, motivation, response, collaboration, active participation, the level of difficulty on use of media, time and troubleshooting techniques pursued by students in the face of difficulties when learning activities take place. Aspects of supporting infrastructure includes a review-a review of the physical facilities and material resources needed as well as students in the learning process such as classrooms,

Criteria for effectiveness in this study refers to: (1) Mastery learning, learning can be said to be complete when at least $75 \%$ of the total number of students have obtained a score of 70 in the improvement of learning outcomes (2) The learning model is said to effectively improve student learning outcomes when statistical results student study showed no significant difference between the initial understanding with the understanding after learning, (3) learning model is said to be effective if it can raise interest and motivation if after learning the students become more motivated to study harder and obtain a better learning outcomes.

\section{Interests and Achievement}

Learning is a process of change in human personality, and the change ditampakkkan in the form of improved quality and quantity of behavior such as increased skills, knowledge, attitudes, habits, understanding, skills, intellect and other abilities (Hakim, 2004: 1). Literally learning has the sense of a conscious activity to get some impression of the material or something that has been studied (Djamarah, 1991: 21).

From the above definition, which needs to be underlined is that the increase in the quality and 
quantity of a person's behavior is shown in the form of increasing the quality and quantity of that person's ability in various fields. Learning is a process of change in the behavior of individuals. Therefore, changes in behavior that lead to good changes can be regarded as an achievement of learning. Learning activities will deliver results in the form of a change in the individual. If in a process of learning one does not get an increase in the quality and quantity of ability, can dikataka sebenarntya person is not experienced learning process or in other words he was a failure in the learning process.

Learning activities should be goal-oriented. The aim of the study is the change activity. Changes expected from the activities of this study is the development of the individual completely. The formulation that learning can be described as a series of activities and soul, psychophysical toward full human personal development involving elements of creativity, taste and intention, cognitive, affective and psychomotor (Djamarah, 1991: 21).

Benjamin S. Bloom dividing learning region they call the educational goals into three parts, namely the cognitive area, kawasasn affective, and psychomotor area. The learning achievement is widely certainly includes the third region of the educational goals. Nevertheless, we will restrict the cognitive learning achievement in any area with an emphasis on the written form of achievement. The learning achievement contains two words which each have an understanding. Therefore, before literally, then it must be defined in advance of each word. The learning achievement is the acquisition of knowledge or skills developed by the subjects, usually indicated by test scores or numerical value assigned by the teacher (WJS. Poerwadarminta, 1991: 787).

From the explanation above, then it can be concluded on terms of learning achievement. Achievement is the result obtained from an activity, while learning is a process that resulted in a change in the individual, namely a change in behavior. With a simple understanding of learning achievement is the result obtained from the form of impressions that resulted in a change in the individual as a result of activity in learning.

\section{Framework of thinking}

The process of learning (PBM) is seen if the quality is effective, meaningful and supported by natural resources. The learning process can be said to be successful if the students showed a high level of mastery of the learning tasks that must be mastered with the object and purpose of learning. Therefore, teachers as educators responsible for planning and managing learning activities in accordance with the demands of learning objectives to be achieved in each subject.
In the learning process, teachers must have a strategy so that students can learn effectively and efficiency, hit on the expected goal. One of the strategies that must be held by teachers is a must master the way - the way of presenting or so-called model of learning.

The learning model is specially planned learning patterns to achieve specific learning goals. In this case the teacher menngunakan learning methods are different than before with the aim that students can think critically, creatively, and develop cooperation between teams in cooperative learning A wide variety of models of learning, cooperative learning model flashcard GAME AND QUIZ-QUIZ TRADE students are expected to be more interested in learning the subjects Basic - Basic Technopreneurship and can provide solutions to understand the material, and provide liveliness, attention, learning to solve problems that can positive effect on student learning outcomes in order to improve teaching and learning. It is expected that students can improve performance.

Target is expected to be reached in this class action research is improving student learning outcomes as a whole on various aspects of students' abilities. The results achieved are measured through the evaluation process, the student's work, attitude assessment, observation, interviews, and others. In order to achieve these objectives, so in this study conducted several stages of the process as the diagram below.

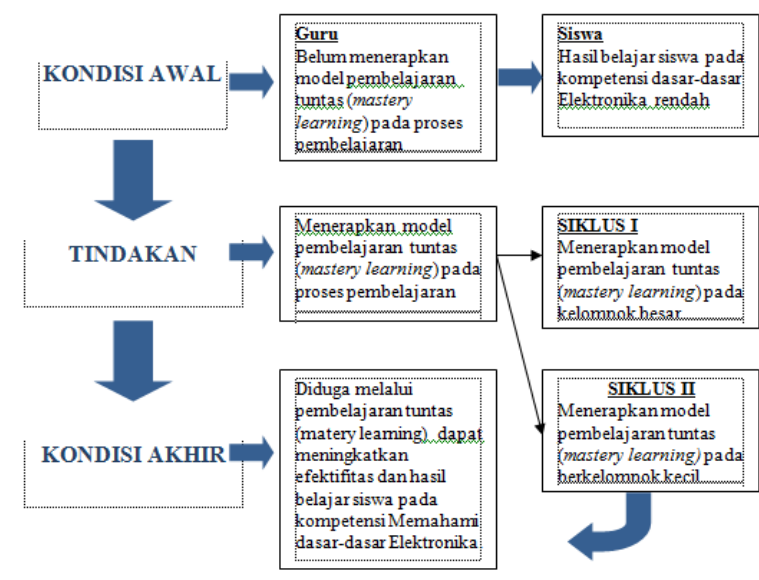

\section{RESEARCH METHODS}

This study was classified as "Class Action Research" two cycles, which aims to improve the skills of learning process and result of class III Preparation Business Establishment A SMK Sales Tempursari. The study also aimed to determine the students' response to the cooperative learning model of the Flash card games and quiz - quiz trade. The 
approach used is qualitative-quantitative. The stages of this study consisted of (1) planning, (2) action, (3) observation and (4) reflection

As the subject of this research is a class XII student of SMK Negeri Tempursari Sales A number of 35 students, consisting of 10 male students and 25 female students. When the study began in January to March 2009 Procedure This classroom action research consisted of two cycles. Each siklusterdiri on 4 stages include: (1) planning, (2) action, (3) observation, and (4) reflection.

\section{Cycle I (3 meetings $6 \times 45$ minutes)}

Highlights to prepare the establishment of business: teknispengurusan user business license, business premises license, permit trading business.

\section{a. plan}

The planning stage includes the following activities;

1. Develop a lesson plan (RPP) the first cycle (Annex la)

2. Setting up the instrument, namely:

a. Performance Assessment of learning Flash card games and quiz - quiz trade (Appendix 2a)

b. Performance Assessment process skills (Annex 2b)

c. Post Test results of study (Appendix 2c)

d. Student questionnaire responses (Appendix 2d)

3. Learning Media

4. Set up a learning resource

\section{b. implementation measures}

Meeting I ( 2 x 45 minutes)

a. Appreciation (5 minutes): teachers' motivation to buy associated with preparing a business establishment.

b. Divide the class into six groups, each group consisting of 6 - 7siswa.Pembagian expert group on the cycle (Annex 3)

c. Assign students in cooperative groups (10 minutes): grouping students from the original group into the group of experts.

d. Preparing students learn cooperatively (6U minutes), students mengerjakanmateri given by the teacher to each group of experts, group discussions if done at the next meeting.

\section{Meeting II ( 2 x 45 minutes)}

a. Students go back to the original group (5 minutes).

b. Students explain the material discussed in the expert group in accordance with respective materials in the original group take turns (30 minutes)

c. Class presentations (technical instructions pengumsan business permit, permit a place of business, trade business license).

d. The teacher pointed to three, lgfagmpok randomly origin untukmempresentasikan result class, while the lainsebagai buffer (45 minutes).

e. Teacher observations (observation) during the presentation kelasberlangsung. V

f. Gum provides reinforcement for the answers given students (10 minutes).

\section{Meeting III ( 2 x 45 minutes)}

a. Gum provides as much as 11 questioning questionnaires about responsiswa toward cooperative learning model of the Flash card games and quiz quiz trade (20 minutes).

b. Gur provide technical instructions on handling posttest ijinusaha, place of business license, business license trading (60min).

c. Teachers give students and record the results pekeijaan hasilnyadalam da fi ar value.

d. Teachers provide individual and group assessment.

\section{c. Observation}

Observations were carried out simultaneously dcngan implementation selumh tindakanterhadap nélaksanaan aspects of cooperative learning model of the Flash card games and quiz - quiz trade, process skills, learning outcomes and student response.

\section{d. Reflection}

At this stage of reflection data analysis to determine whether the class action research has been successful or not. To determine the success of the study determined the following indicators Indicators eberhasilanpenelitian process skills. This classroom action research was successful dalammeningkatkan process skills when the average percentage siswayang do the whole diskriptor minimum reached $85 \%$.

\section{Technique Data Collectors}

Data collection techniques in this research study results collected by using the test in the form of a written test conducted at the end of cycle 1 and the end of the 2 nd cycle. And the observed data collected by observation techniques (observation). Observation makes it possible to determine compatibility between expectation and reality of classroom action research. Observations carried out comprehensively in the classroom. Aspects of observations include: the behavior of students while studying, student discussions, student participation in presentations and discussions. So that it can be seen clearly how the activities of students during the learning process.

\section{Data collection}


Data collection tool in this study are:

\section{Test}

The test is a set of stimulus (stimulus) given to a person with intent to obtain answers that can be used as the basis for scoring points. In this study the type of test used is a test written in the form of multiple choice questions. To get a good test then do steps that make the lattice of test and compile test item in accordance with the lattice of test

\section{Learning Process Assessment Sheet}

Assessment form used to assess the learning process of students in daily tests. This assessment sheet form appraisal formats teaching and learning process.

\section{Observation sheet}

Observation sheet used for the observation of the activities of each student during the learning process. In preparing the observation sheets do steps, namely: (1) Determine the indicators for an assessment of the students' activities were observed during the learning process and (2) Designing observation sheets to be used.

\section{Data validation}

Validation is required in order to obtain valid data. In this study, the data were collected data from test scores cycle I and II and the observed data. To get the data valid test scores then arranged grating questions and test questions. The data were validated through triangulation, ie data derived from the student, the observer (observer) and the researchers themselves.

\section{Results and Discussion}

\section{results}

Results of this Class Action Research include three cycles, each cycle was conducted in three sessions, with an allocation of $2 \times 45$ minutes for each meeting. Learning process focused on achieving the Basic Competence: Ability to analyze the place of business and human resource placement. Cycle one as an assessment whether the Learning Process Approach Flash card games and quiz - quiz trade can run as expected.

Learning Implementation Model Koopera fi $\mathrm{f}$

Flash card games and quizzes - cycle quiz

SatuPelaksanaan trade action on the first cycle was conducted three meetings.

The first meeting

When the teacher entered the classroom, as the appreciation of gum gives two penanyaan.Pertanyaan first is: "Can you cite examples yangharus licenses owned by the company?". When there are several students yangmengacungkan hand want to answer, namely Dwi Fitria, Jayanti, Eka Meilan, and Evika
Mega Put fl to answer, the answer is SITU, SIUP, and IMB.

Kcdua question is "What distinguishes your business license ierscbut third?". When it much allgkat_tangan then appoints one student yaituKamilah Problem. Ydia Kemuadian replied, that "the difference is that THERE ijintempat effort, UP SI business license, whereas IMB building permit.

The next activity is the teacher divides the group into six groups, each group consisting of 5-6 students L.1 <-ztrogen by gender, then divided into 6 groups of experts consisting of 5-6 students. Pembagiankelompok bexjalan smoothly within 5 minutes menempatitempat students already sitting in their group.

Gum divide the material in the original group that tcknik obtaining a business license, permit a place of business, trade business license, how emperoleh 1-credit, ways to minimize esiko banks, non-bank financial institutions. Each member of mendapatkanmateri different groups, then assign students in cooperative groups (grouping students of kelompokdali the original group into the group of experts), students discuss lnateln! which are given by teachers with expert anggotakelompok each with, earnestness and zeal.

Discussion be-rjalan smoothly every group in an atmosphere of enjoy and fun and looks different from the discussions that have been done sebelumnya_original group discussions carried out at the next meeting.

At the second meeting, explanatory phase kenbali students to kelompokasalnya and they bertugas_explains the materials they can be in a group of experts each in turn. At this stage each each member of the group interact with each other, each member of the group to explain the concept in detail and precisely to all group members are stressed-out $\mathrm{fl}$

discussed as a whole, but it also appears frequently asked questions among group members. Benkutnya teacher pointed to three groups at random origin to present the results of the discussion, each group yanh presentation was divided into two sessions, each of which is restricted three questioners while other groups as a buffer. At the time of the presenter deliver presenlasi matcri are quite clear and organized, frequent positive humor, sometimes Benaiah kenada audience in memben audience a chance to fi ber kir. In general, the presenters on the first cycle when the presentation kurangj loud volume, less dare look at the audience, often back to the audience, and there is a small audience of less earnest in following the discussion in the presentation. Teacher observation during class discussions and presentations take place.

At a meeting to fi ga evaluation phase, the end of the implementation cycle erupakan, gum memben'kan questionnaire of 11 questions about 
responsiswa toward cooperative learning model of the Flash card games and quiz - quiz trade and post testsecara memben'kan individually on preparing the business establishment. Problem attached in appendix 2c, during the implementation of the action, do obsewasi by providing student questionnaire responses toward cooperative learning modei Flash card games and quiz - quiz trade. Tabel 4.I rata-rata persentase ketrampilan proses siswa siklus I dan siklus II

\begin{tabular}{|c|c|c|c|}
\hline \multirow{2}{*}{ No } & \multirow{2}{*}{ Jumlah siswa } & \multicolumn{2}{|c|}{ Rata-ratapersentase ketrampilan proses } \\
\cline { 3 - 4 } & & Siklus I & Siklus II \\
\hline 1 & 37 & $80,1 \%$ & $88,1 \%$ \\
\hline
\end{tabular}

From 4.1 tael mentioned above can be explained that the average percentage increase teijadi process skills from the first cycle to the second cycle which means that the cooperative learning model of the Flash card games and quiz - quiz kctrampiian trade can improve the process.

Results were supported jugaoleh above average student posttest results of data analysis.

Tabel 4.2 Nilai rata-rata Post tes dan ketuntasan belajar pada siklus 1 dan siklus 2

\begin{tabular}{|l|c|c|c|c|c|c|}
\hline \multirow{2}{*}{ Pembelajaran } & Nilai rata- & \multicolumn{2}{|c|}{$\begin{array}{c}\text { Ketuntasan } \\
\text { Individu }\end{array}$} & \multicolumn{3}{|c|}{ Ketuntasan Klasikal } \\
\cline { 3 - 7 } & rata post tes & Sudah & Belum & $\%$ & Sudah & Belum \\
\hline Siklus I & 78,7 & 31 & 4 & $88,5 \%$ & V & \\
Siklus II & 88,5 & 35 & - & $100 \%$ & $v$ & \\
\hline
\end{tabular}

Tabel 4.3 Respon Siswa Terhadap Pembelajaran Kooperatif Model Jigsaw

\begin{tabular}{|c|c|c|c|}
\hline \multirow{2}{*}{ No } & \multirow{2}{*}{ Jumlah Siswa } & \multicolumn{2}{|c|}{$\begin{array}{l}\text { Rata-rata persentase respon siswa terhadap } \\
\text { Pembelajaran kooperatif model jigsaw }\end{array}$} \\
\cline { 3 - 4 } & & Siklus 1 & Siklus 2 \\
\hline 1 & 35 & $84,0 \%$ & $85,8 \%$ \\
\hline
\end{tabular}

From table 4.3 above can be explained baliwa average response model of cooperative learning siswaterhadap Flash card games and quiz - quiz trade in the first cycle by $84,0 \%$ dansiklus II amounted to $85.8 \%$, which means terjadj increase student responses from the first cycle kesiklus 11 , In other words, it can be concluded that the model of cooperative learning model Flash card games and quiz - quiz trade can enhance students' response to the model of cooperative pembelajaian Flash card games and quiz - quiz trade. The detailed response models kopoperatif student learning terliadap Flash card games and quiz - quiz trade can be explained as follows:

1. Feeling a lot of unknowns in the lessons Entrepreneurship

2. Kewirausaliaan bennanfaat in their daily lives

3. Satisfied if liasil good learning

4. More Like darapada discussion methods lecture,

5. Model Flash card games and quiz - quiz trade in accordance with the desire of students

6. More senangjika DIBE Fi teacher questions

7. Model Flash card games and quiz - quiz trade increasing boldness argues

\section{Conclusion}

From each result persiklus in the classroom action research found that:

1. Model of cooperative learning methods Flash card games and quiz - quiz trade can enhance the process Sales A class XII student of SMK Negeri Tempursari preparation business establishment.

2.Percentage of student skills in cycle $180.1 \%$ and 88.1 second cycle

3. The method of cooperative learning model of the Flash card games and quiz - quiz trade may improve outcomes

students of class XII SMK Sales A subject

Tempursari preparation business establishment. '

4. Average value of student learning outcomes in the first cycle is the second cycle adalali 78.7 and 88.5.

5. The method of cooperative learning model of the Flash card games and quiz - quiz can trade menjngkatkan class XII student response SMK Sales A subject Tempursari preparation business establishment.

1. 6. The average percentage of students' response to the model of cooperative pembelajamn

2. Flash card games and quiz - quiz trade cycle 1 was $84.0 \%$ and the second cycle was $85.8 \%$.

\section{suggestion}

The teachers of entrepreneurship should apply the model of cooperative teaching Flash card games and quiz - quiz trade as one of learning to improve skills learning process and result siswa.Perlu ulan cont'd classroom action research to improve process skills and student 
learning outcomes so that the learning management more can determine the exact learning model.

\section{References}

Ali Imron. (1996). Belajar dan Pembelajaran. Jakarta: Pustaka Jaya.

Ahmad Rohani. (1995). Pengelolaan Pengajaran. Jakarta: PT Rineka Cipta.

Arikunto, Suharsimi. 2009. Penelitian Tindakan Kelas. Jakarta: Bumi Aksara.

Bambang Prasetyo, Lina Mifhatul Jannah. (2006). Metode Penelitian Kuantitatif. Jakarta: Raja Grafindo Persada.

Depdiknas. (2004). GBBP dan Kurikulum SMK Edisi 2004. Jakarta: Depdiknas.

Dekdikbud. (2002). Kamus Besar Bahasa Indonesia. Bandung: Balai Pustaka.

Kagan, S \& Kagan, M. 2009. Kagan Cooperative Learning. San Clemente: Kagan Publishing.

PengertianBelajardanHasilBelajar.Dalamhttp://duni abaca.com/pengertian-belajar-hasil-

belajar.html.diunduh pada 4 Desember 2011.

Arends, R. I. 2007. Learning to Teach (Belajar untuk Mengajar). Terjemahan Helly Prayitno dan Sri Mulyantini, 2008. Yogyakarta: Pustaka Pelajar.

Becker, Michael; McElvany, Nele \& Kortenbruck, Marthe. Intrinsic and extrinsic reading motivation as predictors of reading literacy: A longitudinal study. Journal of Educational Psychology, Vol 102(4), Nov 2010, 773-785. Google Scholar retrieved 4/11/2014.

Denzin \& Lincoln. 2011. The Sage Handbook of Qualitative Research. Kemmis and Mc. Taggart R. "Participatory Action Research Communicative Action and the Public Sphere". Penerjemah: Dariyanto. Yogyakarta: Pustaka Pelajar.

Gillies, Robyn M. \& Michael Boyle. 2010. Teacher's Reflections on Cooperative Learning: Issues of Implementation. Teaching a Teacher Education. Volume 26, issue 4. Google scholar. retrieved 4/11/2014.

Hanurawan, Soetjipto, dan Prastuti. 2013. Pengembangan Program Pendidikan dan Pelatihan. Perilaku Anti Tawuran Pelajar Berbasis Sikap. FPPsi Universitas Negeri Malang.

Hardre, Patricia L. 2010. Examining Rural High School Teacher Characteristics and Motivating Strategies. Teacher Education and Practice. Volume 23. Google Scholar retrieved 4/11/2014.

Kagan, Spencer \& Miguel. 2009. Kagan Cooperative Learning. Kagan Publishing.
Martin, Andrew J \& Dowson M. 2009. Interpersonal Relationships Motivation, Engagement, and Achievement: Yields for Theory, Current Issues and Educational Practice. Review of Educational Research. Ter.sagepub.com/content/79/1/327.short, retrieved 3/11/2014.

Sapriya, 2012. Pendidikan IPS Konsep dan Pembelajaran. Bandung: PT Remaja Rosdakarya.

Schunk, Dale H, Paul R. Pintrich \& Judith 1. Meece. 2008. Motivasi dalam Pendidikan Teori, Penelitian, dan Aplikasi. Terjemahan Ellys Tjo, 2012. Jakarta: PT Indeks.

Schwinger, M., R. Steinmayr \& B. Spinath. 2009. How do motivational regulation strategies affect achievement: Mediated by effort management and moderated by intelligence. Learning and Individual Differences. Volume 19, Issue 4, December 2009, Pages 621-627. Google Scholar retrieved 4/11/2014.

Shapiro, Lawrence E. 1997. How to Raise A Child with A High EQ A Parents' Guide to Emotional Intelligence? Terjemahan, Mengajarkan Emotional Intelligence Pada Anak, Penerjemah. Alex Tri Kantjono, 1997. Jakarta: PT Gramedia.

Sholihat, Shinta. 2013. Efektivitas Model Pembelajaran Kooperatif Teknik Find Someone Who dalam Meningkatkan Penguasaan Kosakata Bahasa Jepang Tingkat Dasar. Universitas Pendidikan Indonesia.

Bandung. http://repository.upi.edu/id/eprint/5804. retrieved 8/11/2014.

Slavin, Robert E. 2006. Psikologi Pendidikan Teori dan Praktek. Jilid 1. Terjemahan Marianto Samosir, 2008 Jakarta: PT Indeks.

Slavin, Robert E. 2009. Psikologi Pendidikan Teori dan Praktek. Jilid 2. Terjemahan Marianto Samosir, 2011 Jakarta: PT Indeks.

Soetjipto, E. Budi, 2013. Strategi dan Model Pembelajaran IPS. Malang: Pascasarjana Universitas Negeri Malang.

Steinmayr, R. \& B. Spinath. 2009. The importance of motivation as a predictor of school achievement. Learning and Individual Differences. Volume 19, Issue 1, 1st Quarter 2009, Pages 80-90. Google Scholar retrieved 4/11/2014.

Widyasari, I., Suryandari K.C \& Suripto. 2013. Penerapan Metode Permainan Melalui Media Flash Card dalam Peningkatan Kemampuan Kosakata Bahasa Inggris Siswa Kelas IV SDN 2 Kebasen. 
Jurnal Kalam Cendekia. FKIP UNS. http://www.jurnal.fkip.uns.ac.id/index.php/pgsdkebu men/article/ view/2473, retrieved 8/11/2014. 